\title{
Giving up on modern foreign languages? Students' perceptions of learning French
}

Article

Accepted Version

Graham, S. J. (2004) Giving up on modern foreign languages? Students' perceptions of learning French. Modern Language Journal, 88 (2). pp. 171-191. ISSN 0026-7902 doi:

https://doi.org/10.1111/j.0026-7902.2004.00224.x Available at https://centaur.reading.ac.uk/12568/

It is advisable to refer to the publisher's version if you intend to cite from the work. See Guidance on citing.

To link to this article DOI: http://dx.doi.org/10.1111/j.0026-7902.2004.00224.x

Publisher: Wiley

All outputs in CentAUR are protected by Intellectual Property Rights law, including copyright law. Copyright and IPR is retained by the creators or other copyright holders. Terms and conditions for use of this material are defined in the End User Agreement.

\section{www.reading.ac.uk/centaur}

\section{CentAUR}

Central Archive at the University of Reading

Reading's research outputs online 
GIVING UP ON MODERN FOREIGN LANGUAGES? STUDENTS'

PERCEPTIONS OF LEARNING FRENCH

SUZANNE J. GRAHAM

The University of Reading

Institute of Education

Bulmershe Court

Earley

Reading

RG6 1HY

UK

Email: s.j.graham@ reading.ac.uk 


\begin{abstract}
This article reports on the findings of an investigation into the attitudes of English students aged 16 to 19 years towards French and how they view the reasons behind their level of achievement. Those students who attributed success to effort, high ability, and effective learning strategies had higher levels of achievement, and students intending to continue French after age 16 were more likely than noncontinuers to attribute success to these factors. Low ability and task difficulty were the main reasons cited for lack of achievement in French, whereas the possible role of learning strategies tended to be overlooked by students. It is argued that learners' self-concept and motivation might be enhanced through approaches that encourage learners to explore the causal links between the strategies they employ and their academic performance, thereby changing the attributions they make for success or failure.
\end{abstract}

In a recent article, Dörnyei and Csizér (2002) argue from data gathered among Hungarian language learners that a "language globalization process" (p. 421) is taking place, whereby the study of a "world language" (English) is gaining in importance at the expense of the study of "non-world languages" such as French and German. They speculated that in English-speaking countries like the United States and 
England, where "only non-world language learning can take place", this phenomenon has led to "motivationally speaking, a losing battle" (p. 455). In both the United States and England, there are clear indications of this losing battle. Although both countries have experienced some success in increasing the number of students learning a foreign language at the secondary school level, overall up-take is pyramidal in shape, to borrow the analogy used by Lambert (2001) in relation to foreign language enrolments in schools and universities in the United States. He described it as "broad at the base" but narrowing quickly "as [students] progress toward upper-level courses" (p. 350). The Digest of Education Statistics (2001) shows a dramatic decline in the number of Bachelor's degrees earned in French and German over the last 30 or so years in the United States, from a high point in 196970, with 7,624 degrees awarded in French and 2,652 in German, to a low of 2, 514 and 1,125, respectively, by 2001. Spanish is alone in maintaining up-take at around about 7,000 (after a dip in popularity in the 1980s). Schulz (1998), citing a 1996 survey by the American Council on the Teaching of Foreign Languages, referred to the high attrition rate among students enrolled in foreign language courses between grades 9 and 12 .

In England ${ }^{1}$, the decline in foreign language enrolments is particularly apparent in the postcompulsory phase of education, post-16 
years of age (the point at which studying a foreign language becomes optional $^{2}$ ). Since 1992, in England and in neighbouring Englishspeaking countries, there has been a steady reduction in the number of students entering for the French Advanced Level (A-level) examination (see Table 1), a prerequisite qualification for students wanting to go on to university study. Indeed, in the 10 years since 1992, the number of A-level French candidates has approximately halved. This decline is in spite of the fact that the number of pupils studying a foreign language up to age 16 (at which point the General Certificate of Education, or GCSE examination is taken) increased steadily between 1992 and 2003, largely because curriculum reforms introduced in 1992 made studying a language compulsory from 11 to 16 years of age.

\section{<Table 1 here>}

The reasons behind English students' disaffection with foreign language learning post-16 are complex ${ }^{3}$, and there are some indications that the "language globalization process" (Dőrnyei \& Csizer, 2002, p. 421) referred to previously is only part of a wider picture. On the one hand, Chambers (1999) reported that English learners of German in the 11 to 17 age group were aware of fewer opportunities to put their language skills to use than were German students of English of the same age. Graham (2002) found that of 83 students of French aged 16, a quarter wished to give up the subject because it was of no use to their 
career. In the study by Williams, Burden and Lanvers (2002), 228 English learners aged 11 to 13 did not think it was very important to learn a foreign language. On the other hand, Fisher (2001) reported that of 117 English students (at age 16), 69\% felt that foreign languages were valued in commerce and $76 \%$ disagreed with the statement "English speakers do not need to learn languages as everyone else speaks English”. Similarly, Marshall (2000a), in a survey of students in the 16 to 19 age group, found that the students who had chosen not to study a language did not express a lack of interest in languages as a curriculum subject. Some students claimed that it was the pressure of a crowded curriculum that stopped them from opting for languages after age 16, because until 2000, most English students had to choose just three subjects to pursue to A-level. Indeed, the introduction of a new post-16 examination structure in 2000 , whereby students gain an Advanced Subsidiary (AS) qualification at the end of their first year of post-16 study (Year 12), seemed for a while to alleviate the situation. By encouraging students to study a wider range of subjects in their first year of post-16 work, the new framework made more room for the study of a language for students (e.g., science specialists) who previously may have had little opportunity to continue their language learning. Students now usually study four to five subjects instead of the traditional three in Year 12, and then specialise in a smaller number in the second year of post-16 study, Year 13. As a result, in 2000, the 
numbers of language students embarking on a French AS course had increased, by an estimated 35\% (Marshall, 2000b). However, many of these students gave up the subject either during or at the end of Year 12 , leaving the total number completing the A-level course down by $13 \%$ as compared to the previous year. A logical conclusion to draw from these figures is that many students are not encouraged by their experiences of learning French in Year 12.

These experiences seem to be the root of the problem. Even though the evidence is mixed regarding the force of any instrumental orientation for language learning among speakers of English, this force seems unlikely to be strong enough to sustain language learning when it is no longer compulsory. As Chambers (1999) commented, in such a situation teachers must try to "provide a positive in-school experience to compensate" (p. 118) for the relative absence of instrumental reasons for learning a foreign language. Dörnyei and Csizér (2002) implied that learners of languages other than English in other countries, such as Hungary, are also likely to need such compensatory positive experiences. Research, however, suggests that in England students do not perceive modern foreign languages (MFLs) in the 16 to 19 curriculum in a positive light. Instead they see them as difficult (Fisher, 2001; Graham, 2002) and only for the most able. Even those who gain a top grade at 16 and do embark on advanced language study, 
soon lose confidence and feel they are "not good enough for A-level" (Graham, 1997, p. 104). There is some evidence that this perception is prevalent in the United States as well, expressed as a "widespread belief .... that acquiring another language is a special 'gift' that some people have and that most people do not have" (Simon, 1980, in Horwitz, 1988, p. 283). Widening the frame of reference to language learning in general, Dörnyei (2001) argued that "the ability to learn an L2 - often called language aptitude - is a notion that people in general are familiar with and therefore refer to regularly" (p. 119).

English students' lack of confidence in their ability for advanced language study is shared in part by teachers, who for the past decade have expressed concern regarding a perceived mismatch, between the proficiency developed in students up to the end of compulsory schooling at 16 years of age and the demands made on those who decide to continue with languages post-16. GCSE, rooted as it is in a broadly communicative language teaching approach, is seen by many as a qualification designed to develop in students the ability to convey a message, without undue emphasis on grammatical understanding or accuracy. Many of the tasks set in the examination and practised in class are transactional in nature, such as obtaining goods and services, although the up-to-date textbooks widely used in English classrooms try to incorporate some, if limited, cultural insights as well. Post-16 
work, however, demands much more. In Year 12, students are expected to develop their language skills and grammatical knowledge rapidly within the space of 8 months, so that they are able to show proficiency in, for example, manipulating the foreign language accurately, "to organise facts and ideas, present explanations, opinions and information". Year 13 students are required to show, in addition, "greater depth of understanding of culture [...] a high level of critical awareness.... [the ability to] analyse, hypothesise, evaluate, justify a case, persuade, rebut, develop arguments [...] demonstrate a capacity for critical thinking" (QCA, 2001). Given this element of "curricular discontinuity" (Stables \& Stables, 1996), there seems little wonder that for many learners and teachers, becoming an advanced language learner is similar to "reaching the promised land", in the words of the title of Dupuy and Krashen's (1998) paper on the gap between lower- and upper-division language classes in the United States.

\section{THEORETICAL BACKGROUND}

Of course, possible influences on foreign language learning motivation are numerous, and the role played by such factors as the teacher, materials, and instructional approaches have been widely discussed in the literature. A question that has received rather less attention, however, is the possibility that students' desire, or otherwise, to pursue language study when it is no longer compulsory is influenced 
by the degree to which they feel able to meet this challenge, or, to use a term developed in the work of Bandura in a number of publications (e.g. Bandura, 1995), their degree of self-efficacy. This construct has been applied widely in general educational contexts but to a lesser extent in the study of language learning motivation. An indication of its relevance for language learning is found in the call made by Oxford and Shearin (1994) to broaden the motivational research agenda to include approaches used in other fields of enquiry. They commented on the important influence exerted by learners' expectancies of success or failure on their motivation to learn a foreign language. Likewise, Tremblay and Gardner (1995) considered self-efficacy to be an important antecedent to motivational behaviour in language learning (e.g., persistence) and define it as "an individual's beliefs that he or she has the capacity to reach a certain level of performance or achievement" (p. 507). In one of the few studies to consider the role of self-efficacy in language learning, Yang (1999), in a study of EFL learners in Taiwan, found a strong positive link between learners' selfefficacy beliefs and their learning strategy use. Looking at the link between self-efficacy and achievement in adult language learning, Ehrman (1996) identified a positive relationship between high selfefficacy, end-of-training ratings in speaking and reading and scores on the Modern Language Aptitude Test (MLAT). In this and other studies, however, it is not absolutely clear whether high levels of self- 
efficacy and motivation led to higher proficiency, or whether low proficiency (perhaps caused by poor strategies) led to low self-efficacy and hence low motivation. Ganschow, Sparks, and Javorsky (1998) suggested that low motivation results from language learning difficulties, not the other way round. By contrast, with reference to learning in general, Zimmerman (1995, citing Bandura, 1993) argued that efficacy beliefs and their impact on motivation "contribute to academic performance over and above actual ability" (p. 213).

Self-efficacy is in turn held to be influenced by the explanations individuals give for their success or failure on tasks or by the attributions they make (Bandura, 1995). Attribution theory originates in the work of Weiner, and argues that individuals have a desire to seek out and give explanations for perceived success and failure, particularly in circumstances where the outcome is unexpected, that is,. failure when success was expected and vice versa. The attributions that individuals use to explain achievement in academic fields were originally considered to fall into one of four categories: ability, effort, luck, or task difficulty (Weiner, 1984). Although Weiner admitted that the range of possible attributions may be much wider and depends on the context in which the attributions are made, he mentions only in passing a factor that occupies an important place in language learning research: the role of learning strategies. Other researchers have 
recognised that learners may well attribute learning outcomes to learning strategies employed on a task, that is, to the "specific actions taken by the learner to make learning easier, faster, more enjoyable, more self-directed, more effective, and more transferable to new situations" (Oxford, 1990, p. 8). Chan (1996), for example, investigated the attributions made by gifted and average students for success or failure in first language (L1) reading and reported that gifted students were more likely than average students to attribute success to effort and failure to lack of effort and ineffective strategies.

Chan (1996) concluded from her findings that gifted students "tended to have greater confidence in their personal control over learning outcomes, believing that ... should they fail, it would have been because of a lack of effort or non-use of strategies but not because of lack of ability or bad luck" (p. 189). This conclusion reflects the view in attribution theory that the kinds of attributions individuals make for success or failure are likely to affect expectations of future success or failure, that is, self-efficacy, and hence motivation to repeat similar tasks. Students with adaptive or positive attributional styles may well attribute success to high ability and perceive this ability as a fairly stable and internal factor. Their motivation to attempt similar tasks is therefore high. Attributing failure to lack of ability and viewing ability as a fixed entity (Dweck, 1987) and hence as an 
uncontrollable factor, constitutes a maladaptive style and is likely to dampen motivation to attempt similar tasks. In its most extreme form, such an attitude constitutes learned helplessness (Dweck \& Repucci, 1973; Seligman, 1975), whereby effort is seen as pointless because success appears impossible. Williams et al. (2002) reported that lowerachieving students of languages in their survey were at risk of developing this tendency, "in that they perceived far less actual and potential rewards for their efforts than did more highly achieving students" (p. 524).

Attributing success or failure to strategies employed, however, can be viewed as a positive tendency. For example, explaining failure by poor strategies selected and employed may turn such outcomes "into problem-solving situations in which the search for a more effective strategy becomes the major focus of attention" (Clifford, 1986, p. 76). Although ability attributions for success are generally held to be adaptive, there is the danger that individuals who feel that ability is the sole cause of their achievement may become complacent (Noel, Forsyth, \& Kelley, 1987). Strategy attributions avoid this problem, being controllable and mutable as well as internal to the individual. As such, they should foster improved motivation in learners. The importance of strategy attributions is underlined by Dickinson (1995), writing about learner autonomy in language learning: 
“...learning success and enhanced motivation is conditional on learners taking responsibility for their own learning, being able to control their own learning and perceiving that their learning successes or failures are attributed to their own efforts and strategies rather than to factors outside their control. Each of these conditions is a characteristic of learner autonomy as it is described in applied linguistics." (p. 174)

Dörnyei (2001) argued that there is a risk of pupils making negative ability-attributions in relation to foreign language learning, rather than more positive effort or strategy based arrtributions, as they may feel that they are just no good at a subject for which a particular aptitude seems necessary. Williams and Burden (1999) asked English pupils (aged 10 to 15) what they felt was important for "doing well" in foreign languages. Very few pupils mentioned the importance of using effective strategies to improve their performance. The authors interpreted this finding as a sign that the messages contained within the learning strategies research literature "may not be filtering through to teachers in the language classroom" (p. 199). This conclusion supports the finding by Graham (1997) that very few teachers working with advanced learners in England spent time on promoting learning strategy use. 


\section{AIMS OF THE STUDY}

To what extent can such a theoretical framework illuminate our understanding of how students in the 16 to 19 age group perceive language learning and the consequent influence it may have on their motivation to persist with language study? This question was explored in the present study, which set out to investigate a number of questions relating to students' perceptions of French, not all of which are reported fully here (see Graham, 2002, for a full consideration of questions relating to students' reasons for giving up French at age 16 and their perceptions of their achievement in different language skill areas). This article reports on the following questions, which were central to the project:

1. How do students perceive their level of achievement in French, in terms of expected examination grades and a more global self-assessment?

2. To what reasons do students attribute their achievement?

3. How do these attributions relate to achievement - predicted, actual, and perceived - and the desire to continue studying French post-GCSE? 


\section{STUDY DESIGN}

\section{Participants}

The first part of the study (the questionnaire, see Appendix A) was conducted among learners of French in 10 educational institutions in the South of England. All schools involved in Reading University's Initial Teacher Education Schools Partnership for foreign languages were invited to take part, plus one school in another area, and 10 agreed to do so. Learners in three academic year groups were studied: Year 11 (last year of compulsory schooling, leading to the GCSE examination at age 16); Year 12 (first year of postcompulsory schooling, leading to Advanced Subsidiary/AS); Year 13 (second and final year of postcompulsory schooling, leading to Advanced Level/A-level). Numbers from each year group are shown in Table 2. From this larger sample, 28 students were selected for interview to pursue themes highlighted in their questionnaires. These students were chosen to give a broadly balanced sample in terms of gender, year group, proficiency (in terms of predicted and achieved examination results), and desire to pursue French post-GCSE (for the Year 11 students). The students were selected in consultation with their teachers and based on their questionnaire responses, in order to give the range indicated above. Thus a form of "purposive" sampling was used (Cohen \& Manion, 1990). This article will focus principally on findings from the questionnaire data. Data from the interviews will not be analysed fully 
here because of lack of space, but selected aspects will be used to illuminate the data from the questionnaire.

\section{<Table Two here>}

The GCSE examination is typically taken after 5 years of language study and the majority of pupils are grouped by ability (or

set). In order to gain the views of those pupils who were most likely to have the potential to continue French after GCSE, the Year 11 sample included only those students who were in the top ability set in their school.

\section{Instrumentation}

The questionnaire was developed from one used in an earlier major study of UK Year 12 students (Graham, 1997) and incorporated elements adapted from Chan (1996) and Williams and Burden (1999). It went through two pilot stages, in which a different group of students (Years 11, 12, and 13) completed the questionnaire with the researcher, commented on its clarity and their understanding of the questions, and talked about their perceptions of studying French. During this piloting it was apparent that learners were able to comment constructively on how they perceived their achievement in French and on the supposed causes for it. Important issues identified were: (a) contradictions between how well they felt they were doing and their teachers' view; 
(b) the amount of effort needed to do well in French; (c) areas of success and lack of it, and (d) explanations for their performance. Items were developed to explore these themes combining closed and open-ended questions. Each year group completed a slightly different questionnaire, taking into account which examinations they had taken and which they were about to take. For reasons of space, these three questionnaires are not reproduced in their entirety in Appendix A. Instead the items relevant to the questions explored in this article are given.

A review of recent literature relating to attribution theory (e.g., Tse, 2000; Williams \& Burden, 1999) suggests that a purely quantitative approach to data collection, typically presenting respondents with a range of causal explanations for achievement and asking them to select those explanations that apply to them, has led to limited data that do not properly take into account the respondents' perceptions of the reasons behind their achievement. For this reason, questions requiring both free and structured responses were posed. First, the students were asked to complete sentences to describe reasons for doing well or not so well in French in general (see Appendix A), so that they had the opportunity to explain in their own words what they felt the reasons for their overall achievement in French might be, rather than just focussing on specific skill areas. Attributions for perceived success or lack of it 
in specific skill areas were then investigated. Respondents were asked to indicate on a 6-point scale the extent to which they felt various factors (ability, effort, luck, strategies, task difficulty level) explained their learning outcomes. These factors were chosen as the attributions most commonly considered in the literature (e.g., Chan, 1996; Tse, 2000; Williams \& Burden, 1999). Thus a "causal attribution wording style" was employed as described in Whitley and Frieze (1985). These authors, in a meta-analysis of research into children's causal attributions in achievement settings, claimed that causal attribution wording style has greater content validity than informational wording, which asks respondents "the extent to which they possess ability and luck in regard to a task, the extent to which the task was easy or difficult, and the extent of their effort on the task" (p. 609). In addition, space was given in this part of the questionnaire for respondents to write in an alternative or additional explanation, in order to ensure that other possible responses were not being closed off.

During piloting, students were asked to comment on the wording of the questionnaire, to ensure that it was comprehensible and to investigate its content validity. Another important factor in the development of the questionnaire was its length. Given the timepressures under which language students and teachers are working in this stage of education in England, it was important to produce a 
questionnaire that could be completed in 15 minutes. Any issues not fully explored through the questionnaire were then followed up in the interviews.

The final version of the questionnaire was completed by students, in class, between October and November 2001. Respondents were assured of anonymity and informed that their participation was entirely voluntary.

The interview schedule was drawn up after an initial analysis of the questionnaire data, which focussed on important themes that emerged, such as the students' concept of themselves as language learners and their views on the respective contributions of effort and ability to successful language learning.

Analysis

Given that ordinal scales were used in the questionnaire and no distributional assumptions were made about the data, nonparametric statistical methods were employed in their analysis. For questionnaire items relating to the students' examination grades (self- and teacher predicted, and those already achieved), simple frequencies and percentages were calculated. Examination grades were placed on an ordinal scale of 1 to 8 for GCSE (i.e., highest GCSE grade, $\mathrm{A}^{*}=8, \mathrm{~A}=$ 
7, etc.), and 1 to 5 for A- and AS-level (i.e. highest grade, $A=5)^{4}$. An important aspect of the research question that aimed to explore students' perceptions of their level of achievement in French was their sense of self-efficacy regarding the likelihood of their achieving the examination grade that had been predicted by their teacher. This sense of self-efficacy was investigated by comparing the students' predictions and those that they claimed their teacher had made, for Years 11 and 13 only ${ }^{5}$. The standard nonparametric test for differences between paired observations, the Wilcoxon matched-pairs signed-ranks test (see, e.g., Bryman \& Cramer, 2001; Siegel \& Castellan, 1988), was used for this purpose.

A 6-point scale was used to elicit further the students' perceptions of their level of achievement: (a) How well they thought they were doing in French; (b) how hard they would have to work to achieve their hoped-for grade; and (c) how hard they had had to work for their GCSE or AS grade (Years 12 and 13 only). Again, simple frequencies and percentages were calculated.

The same calculations were made to analyse the students' attributions for achievement, in the form of an expressed level of agreement with five attributional statements as explanations for their success or lack of it in specific language skills. In order to ascertain 
whether there was an overall significant difference in the extent to which students agreed with the different attributional statements, the Friedman two-way analysis of variance test was used, the nonparametric equivalent of a repeated measures ANOVA. This test was followed by a post hoc multiple comparisons test (the Wilcoxon matched-pairs signed-ranks test ${ }^{6}$ ) to determine more precisely where such differences lay.

It was predicted that three independent groups of Year 11 students, those students who wished to continue French post-16, students who did not, and students who were uncertain, might differ in the attributions they made for success or lack of it. In order to explore this question, the Kruskal-Wallis one-way analysis of variance test was applied, followed by the Mann-Whitney-U test ${ }^{7}$ as a post hoc multiple comparison test.

In order to investigate the relationship between attributions and the students' achievement (past, predicted, and perceived, in terms of how well the students felt they were doing), correlation coefficients were calculated (Spearman's Rho).

The students' responses to open-ended questions relating to attributions were analysed and coded and frequencies for each type of attribution 
tabulated for each year group. Although some students gave more than one reason for doing well or not so well, for the sake of clarity and simplicity, only the first reason given by each student is reported here. The codings arose partly from categories most commonly found in the literature of attribution theory, that is, ability, effort, task, luck, and strategy use, but where these categories were deemed insufficient to account for the students' explanations for their achievement, additional categories were created, for example, concentration. The reliability of the coding was checked by having $10 \%$ of the questionnaires recoded by a research assistant and having these codings compared with those of the researcher. An interrater reliability figure of $96 \%$ was found. The same procedure was used when analysing the students' reasons for studying, or not studying, French post-16 and their explanations regarding the effort they had expended during their French studies.

\section{RESULTS}

\section{Research Question 1}

How do students perceive their level of achievement in French, in terms of expected examination grades and a more global selfassessment?

Expectations and Experiences of Success. Information on the students' examination achievements, past and anticipated (by themselves and by their teachers) was gathered (Appendix A, Items 7, 
$10,12,15,16$, and 18). Tables 3 and 4 show that all year groups contained high-ability linguists. The vast majority of students achieved one of the top three grades or had such a grade predicted by their teachers. Only in Year 11 was there a significant difference between the examination grades predicted by the students and by their teacher (Wilcoxon matched-pairs signed-ranks test, $z=-5.251, p<0.000$ ), with teachers predicting higher grades (Table 4). It is interesting that when the data for boys and girls were examined separately, such a difference was found only for the girls' predictions, who underestimated the grade they anticipated compared with the one predicted by their teacher $(z=-$ $6.047, p<.000)$. This may indicate a lower sense of self-efficacy among girls than among boys. Table 5 gives descriptive data for the predictions made by boys and girls in Year 11, and those made by their teachers.

\section{$<$ Tables 3, 4 and 5 here $>$}

Students' Global Self-assessment. Insights into students' perceptions of how well they felt they were performing in French, without reference to examination grades, were gathered from questionnaire item 1, which the students scored on a scale from 1 to 6 , with 1 indicating I am doing very badly in French and 6, I am doing very well in French. 
In Year 11, only $41 \%$ of the students felt their achievement warranted a 5 or a 6 , a relatively small percentage given that $68 \%$ were expecting to gain one of the top three GCSE grades. Furthermore, within this overall figure there were a number of Year 11 students (39) who, despite being predicted to receive one of the top two grades by their teacher, did not feel they were doing very well at French. Of these students, 35 predicted for themselves a grade at least one point lower than the grade their teacher expected them to achieve. It is interesting to note that 31 of the 39 students were female, that is, $20 \%$ of the Year 11 girls - who again seemed particularly likely to underestimate their ability in French. One female student, for example, expected a grade A-B compared with the top A* predicted by her teacher, and wrote that she did not "feel that confident in French".

Other questionnaire comments further suggested that for some students, getting what is usually considered to be a good grade does not mean the same thing as doing well in French. This finding is in line with that of Tse (2000), who reported that of 51 adult language learners in the United States, there was only one who equated success with good grades. In the present study, one Year 11 female student was predicted a top GCSE grade by her teacher and believed herself that she would attain this grade. Nevertheless, she rated her achievement in French as only 4 out of a possible 6 and wrote: "I know even tho [sic] I am 
acheiving [sic] high grades that I have v. poor ability in writing/speaking/understanding French.” In the interview she elaborated on why she felt she was achieving only moderately well, in spite of her high examination expectations: "I can get across my point in French, if I have to, but it wouldn't be anyway near good French ... me and my friends, we're predicted very high marks, a lot of my friends get very high French grades and we couldn't hold a conversation in French.”

Again, this observation mirrors the situation reported by Tse (2000), of students claiming to gain straight A's without achieving "any functional fluency" (p. 78). Both Tse (2000) and Horwitz (1988) questioned whether students are given realistic expectations of the proficiency they can achieve in a fairly limited time. The present data would suggest that in England at least, they are not.

The perceptions of Year 12 and 13 students were similar to those of Year 11 students, with only 66 (33\%) of Year 12 students and $45(42 \%)$ of Year 13 students indicating that they felt they were performing at the 5/6 level. The "dip" at Year 12 may reflect the increase in difficulty, and hence the decrease in perceived achievement, by the students beginning advanced work, a feeling that may be particularly acute for students who are used to experiencing success in foreign language 
learning. As one Year 12 student commented in the interview, this feeling may affect students' sense of being able to cope with the increase in difficulty: "There seems to be such a big gap between my French GCSE and A-level. I can't sort of, an, like, motivate... it seems to wash over me sometimes."

Effort-Anticipated and Expended. Respondents were asked to indicate on a scale of 1 to 6 their perceptions of the effort needed to gain their hoped-for examination grade, and the effort they felt they had expended in earlier French examinations (Years 12 and 13). The low end of the scale indicated working Not hard at all to get the grade, the high end working Very hard (Appendix A, Items 8, 11, 13, 17, and 19). The vast majority of advanced students (93\% in Year 12, 88\% in Year 13) claimed that they would have to work hard or very hard to achieve the grade they hoped for ( 5 or 6 on the 6-point scale).

By contrast, relatively few Year 13 students (41\%) seemed to feel that they had worked hard or very hard the previous year. Where the students chose to explain why they had ranked their effort as they did, the most frequently noted response was that they had not worked as hard as they could or should have in Year 12 (given by 28 Year 13 students or 26\%). Perhaps these students were acknowledging a degree of complacency on their part when they were in Year 12, a complacency possibly prompted by their earlier success and a strong 
sense of "being good at French". There is some support for this supposition in the interview data, where students, such as the following Year 13 female student, spoke of their assumption that some kind of "natural ability" would carry them through in Year 12:

...last year, um, in Year 11, I was really good at French, got an $\mathrm{A}^{*}$, and [...], I took it easy last year [Year 12] cos I thought...cos French was my best subject, and I thought, 'Yeah, don't need to work that hard'."

A similar degree of complacency is detectable in the responses made by many Year 12 students, when assessing how hard they had needed to work to achieve their grade for the GCSE (with only $32 \%$ claiming they had worked hard or very hard). Comments made by the students to explain this lack of effort referred to the supposed ease of the GCSE (37 students), to their own failure to have worked as hard as they could or should have (18, with 5 of these claiming to have done the bare minimum of work), or to their concentration of effort on the oral examination (16). These attitudes reinforce the view expressed above, of students gaining the impression that natural talent or aptitude will inevitably lead to success in language learning. For many advanced level language students, the consistent effort needed in advanced level courses is likely to be a rude awakening. This view was expressed by one male Year 13 student, who, after gaining a top grade 
at age 16 and then a poor grade of D at AS-level, commented in the interview: "It's a lot harder at A-level, it was easy at GCSE and that was one of the reasons I took it at A-level, cos I thought, 'Ah, French is easy'.,

Reluctance to become an advanced language learner. Yet for many Year 11 students, French is anything but easy. When asked "Do you hope to study French at AS- or A-level?” (Item 9, Appendix A) only 55 , or $19 \%$ of 286 Year 11 students reported that they intended to continue studying the language after age 16 . The four most frequently cited reasons for not continuing were (a) that they did not enjoy it (35 students), (b) it was difficult (25 students), (c) it was of no use for their planned career (23 students), and (d) they were not good at it (20 students), "not good enough to study French AS- or A-level", as one male student expressed it on his questionnaire, despite his teacher's prediction that he would receive an A in the GCSE examination.

Research Question 2

To what reasons do students attribute their achievement?

Further insights into the students' perceptions of their achievement in French were obtained from the explanations they gave for their success or lack of it in the subject. The students were first 
asked to give these explanations in general terms, by completing two sentences (see Item 2, Appendix A). They were then asked to identify one skill area each in which they felt they had achieved the most and the least success respectively, (Items 3 and 5), and to give causal attributions for this achievement (Items 4 and 6). The areas of least success for Year 11 students were speaking and writing, for Year 12 and 13 students, listening. The students gave explanations for their success or lack of it by indicating their level of agreement with a series of statements (see Appendix A).

The open-ended and closed attribution questionnaire items thus asked the respondents to comment on different areas of their learning, and employed different forms of elicitation. For these reasons, the following presentation does not attempt a detailed comparison of the results from the global and specific attribution items, although certain similarities and differences that are considered noteworthy are discussed.

Global Attributions. Table 6 indicates that for overall achievement in French, Year 11 students see ability as the most important factor for success, and for Year 12 students, effort is in first position, marginally ahead of ability. For Year 13 students, ability is viewed by only $8 \%$ of the year group as an explanation for overall 
success, with effort and strategy use seen as more important. For all year groups, two additional attributions, interest and concentration, are mentioned as reasons for doing well, with the latter cited by a sizeable proportion of the Year 11 group. These students would have been taught in groups larger than those found post-16, with perhaps as many as 36 pupils, not all of whom would be highly motivated or focussed in French. This large class size may explain the importance of maintaining concentration for the younger students.

\section{<Table 6 here>}

The greater emphasis on ability than on other achievement factors in Year 11 again indicates the perceived importance among intermediate students of being good at French for doing well. As far as strategy use is concerned, relatively little importance was attached to this aspect of language learning, although the older students seem to place more emphasis on it than the younger students. This difference reflects the findings of Williams and Burden (1999) referred to earlier. They found that very few younger students of French mentioned the importance of effective strategies for doing well. Year 13 pupils, as argued earlier, having completed 1 year of advanced level study, may have a greater understanding of the need for effective working behaviours and all-round effort in order to achieve in post-16 French, rather than relying on natural ability alone. 
As far as lack of success is concerned, for the Year 11 and 12 students, the most common attribution was low ability. This attribution is usually held to be a maladaptive attribution in that it can adversely affect motivation to persevere in the face of difficulty. Attribution theory suggests that such motivation is stronger if failure is attributed to factors within one's own control, such as low effort expended or poor strategies used. For Year 11 and 12 students, there was relatively little importance attached to these factors for lack of success. Again, Year 13 students alone seemed to recognise that lack of success might be due to insufficient effort. Tse's (2000) older, adult language learners also largely attributed their past lack of success to insufficient effort on their part. It is interesting to note that very few learners of any age in the present study referred to the importance of their teacher for their success or lack of it, unlike the learners studied by Tse (2000).

Attributions for Specific Skills. Tables 7 and 8 show the extent to which the respondents in each year group agreed with the given attributional statements for success and failure.

\section{$<$ Tables 7 and 8 here>}

Once the Friedman two-way analysis of variance had shown that, overall, for success and failure in each year group, there were significant differences between the attribution scores $(p<.0001)$, the exact nature of these differences was explored by conducting post hoc 
multiple comparisons between the three most favoured attributions for both success and failure (Wilcoxon matched-pairs signed-ranks test). The results of these comparisons are given in Table 9. For Year 11 and 12 students, effort is seen as a more plausible explanation for their achievement in specific skill areas than either ability or strategies. Effort, together with ability, is one of the attributions for success most commonly identified in Western cultures (Graham, 1994) and is generally held to have a positive influence on motivation. The Year 11 students seemed to place more emphasis on effort for specific skills than they did for overall achievement, which is perhaps an indication that they concentrated their efforts on specific targets. For the Year 13 students, the picture is more complex. Ability was viewed by only $8 \%$ of the year group as an explanation for overall success, but for specific skills it was rated highly (more highly than strategy use). Perhaps, unlike Year 11 pupils, they felt that "talent" or ability is more relevant to success in discrete skill areas. Scores for effort were also higher than those for strategy use. In all year groups, therefore, relatively little importance was attached to strategy use in doing well in specific skill areas.

\section{<Table 9 here>}

Similar results were found for attributions for areas of least success. Low ability and task difficulty were the most important 
attributions for Year 11 and 12 students, who saw them as more plausible explanations for lack of success than poor strategies. In Year 13, there were no significant differences between attributions for strategy use on the one hand and ability and task difficulty on the other, this group being apparently the only one with insight into the role played by poor strategies in areas of difficulty.

Although these older students seemed to recognise the importance of low effort as a contributory factor to poor performance overall, for specific skills, they did not attribute lack of success firmly to it. Perhaps by this stage in their language learning career, any difficulties that persisted were considered immutable, caused by innate factors that effort had been unable to overcome. This view was in fact expressed in interview by a Year 12 student, who was asked to comment on the disparity between her overall failure attribution (low effort) and her attribution for lack of success in listening (low ability). She explained: "Well, I think that's because that's my weakest area, perhaps however much I do there I'm still going to be weaker."

Furthermore, for specific skills, the percentages in the Agree and Agree strongly columns were relatively low, suggesting that the students were unable to identify very clearly explanations for their lack of success. This finding indicates perhaps a low level of metacognitive 
awareness, similar to that found by Williams et al. (2002) among younger learners in England. In the present study, the students were invited to write down additional or alternative explanations for their lack of success. Of those who did not agree with any of the reasons suggested for failure, a relatively small percentage gave additional reasons (in Year 11, 9\%, Year 12, 15\% and Year 13, 17\%). Space does not permit a full analysis of the reasons given, but certain aspects are worth noting. For Year 11 students, the most common additional reasons given related to ability when the area of least success was writing, speaking, or grammar; when the area in question was listening, the most common reasons were ostensibly the difficulty or nature of the tasks and the poor quality of audio material. Similar reasons were given by Year 12 and 13 students with reference to listening, whereas for speaking, anxiety was the most common additional reason given to explain lack of success. However, in the case of listening, a closer analysis of comments referring to task difficulty or poor materials revealed that they also indicated problems arising because of poor strategies - for example, listening for each word and then being left behind when side-tracked by an unknown word. Yet 16 of the 19 students who made these comments did not agree with the statement provided on the questionnaire that attributed lack of success in listening to poor strategy use. A possible explanation for this finding is that these students were simply unaware that the strategies they were using 
are ineffective - or indeed that more effective strategies exist for listening comprehension.

\section{Research Question 3}

How do these attributions relate to achievement - predicted, actual, and perceived - and the desire to continue studying French post-GCSE?

Tables 10 and 11 present the ratings for specific attributions of students who hoped to continue with French post-16 (continuers) and those who were either unsure (not-sures) or wished to give it up (noncontinuers). Once the Kruskal-Wallis one-way analysis of variance had shown that, overall, for success and failure, there were significant between-group differences in attribution scores $(p<.05)$, except in the case of task ease and bad luck, post hoc multiple comparisons were made (Mann-Whitney U test) to explore these differences further. Table 12 presents the results of these comparisons. The results suggest that noncontinuers are less likely to attribute success to effort, strategy use, and ability, and more likely than other students to attribute it to luck or chance, indicating a poor sense of their own agency. Likewise, they are more likely than continuers and notsures to attribute lack of success to their own supposed low ability. Compared with the students expressing a desire to study French post- 
16 , they are also more likely to blame failure on task difficulty, lack of effort and poor strategies. The not-sures also differ from the continuers in this respect. Although one would expect this difference relating to task difficulty, in that blaming lack of success on this factor indicates a degree of passivity and low motivation, the findings regarding effort and poor strategies are more surprising. One would expect students with greater self-efficacy and motivation to attribute lack of success to factors over which they had some control, that is, to insufficient effort and ineffective strategies, as was the case for the gifted students in Chan's (1996) study. The reasons behind the response of continuers here are unclear. They expected a higher GCSE grade than noncontinuers, within a top school set, and so are comparable to Chan's gifted students. Perhaps for continuers, their area of least success is a relative one, in which by most people's standards they are doing well, and in which effort is being expended and reasonably good strategies are being applied. Or it may be that even able linguists are not particularly skilled at analysing the reasons for any lack of success they experience.

\section{<Tables 10, 11 and 12 here>}

These explanations may also clarify one of the findings regarding the relationship between attributions and achievement (actual, self-predicted, and perceived), investigated using Spearman's 
Rho correlation coefficients (see Tables 13, 14, and 15). It was hypothesised that there would be a positive relationship between adaptive failure attributional tendencies, that is effort and strategies and achievement (self-predicted, actual and perceived) and a negative relationship between maladaptive attributions - ability and task difficulty - and achievement. That is, more proficient students would explain lack of success with reference to factors within their control effort and inefficient strategies. For all three year groups, the higher the students' sense of achievement, the less likely they were to blame failure on task difficulty and low ability - that is, to factors beyond their control. Hence more highly achieving students, or those who believe they are achieving, are less prone than less successful students to passive explanations for lack of success. Yet at the same time, there are also negative correlations between achievement on the one hand and attributions for poor strategy use on the other in all years, perhaps for the reasons outlined above regarding the failure attributions of continuers.

\section{<Tables 13, 14 and 15 here>}

For areas of most success, it was hypothesised that there would be a positive relationship between adaptive success attributions, ability, effort and strategies and achievement (self-predicted, actual and perceived), and a negative relationship between maladaptive attributions and achievement. Table 13 indicates that for Year 11 
students, this hypothesis was verified (although correlations are weak). That is to say, the higher the GCSE grade that students anticipated receiving, and the higher they rated how well they were doing in French, the more likely they were to attribute success to high ability, effort, and good strategies, the less likely to good luck. In Years 12 and 13 (Tables 14 and 15), fewer adaptive attributions were correlated with high grades and sense of achievement - ability for Year 12, and ability and strategies for Year 13.

\section{DISCUSSION AND CONCLUSIONS}

The study aimed to explore students' perception of their achievement in French. The data reveal that this was a high-ability group of students, who either expected to gain a high grade at the end of postcompulsory education or had already achieved one. However, it is noteworthy that few Year 11 pupils expressed positive attitudes towards French, in an ability group that would suggest that they were the students most likely to pursue the language post-16. Furthermore, pupils who were predicted high grades were not widely convinced that they were doing well at French. Possibly an indication of low selfesteem, this finding might also suggest that students do not feel that success in an external examination is necessarily the same thing as achieving linguistic proficiency. Similarly, although many felt that their 
predicted examination grade would be relatively easy to attain, many others cited the perceived difficulty of French as a subject as a reason for giving it up after 16 years of age, as well as the lack of interest they had in it. This finding may be a sign that unrealistic demands are being made of these learners, that their language course is indeed too hard for them, or it may reflect a perception shared with some other populations that "L2 learning is difficult" (Tse, 2000, p. 82) and that they are illequipped to cope with such difficulty.

Year 13 students were more inclined to claim they felt they were doing well, but Year 12 students were less sure about their level of success, with nearly half of them feeling they were doing only reasonably well or badly. Expectations of examination success were not quite so high for the post-16 students and they felt that a lot more effort would be required to gain their hoped-for grade than was the case prior to advanced level work.

In terms of the reasons students attribute to their successes or failures in French, the responses to the questionnaire suggest that for this sample, high ability and effort are the most common attributions for specific areas of success for all three year groups. These attributions, along with strategies, correlate positively with expected examination grades and self-ratings in French for Year 11 pupils. 
Attributions relating to ability (Year 12) and ability and strategies (Year 13) correlate positively with achievement (actual, expected, and perceived). Furthermore, those who wish to pursue French post-16 are more likely than noncontinuers to attribute success to effort, ability, strategies employed and less to luck. Thus, perceiving the link between these personal characteristics and outcomes seems to have an important motivating influence for this group of students.

The most common attributions for lack of success are perceived low ability and task difficulty. These attributions correlate negatively with anticipated examination grades for each year group. This finding suggests students who may become prone to low motivation and to passivity in the face of difficulties, with success appearing unattainable. The low levels of effort and strategy attributions may indicate a reluctance to accept responsibility for one's own lack of success, or a sense of mystification as to how to improve one's language learning. Possibly these students believe they are trying reasonably hard but are unaware that their efforts are being inappropriately focussed. That is to say, their efforts are not being applied efficiently or strategically, and the students display a low level of metacognitition, "the learner's own personal 'executive control' over his or her own learning” (Oxford, 1996, p. xi). 
Although the study has focussed on a specific group of students, its findings have implications for wider language learning, particularly in those contexts where language learning has little instrumental value. Furthermore, if lack of or only limited success in foreign language learning is a relatively frequent phenomenon (as claimed by Dőrnyei, 2001, and Stern, 1983), then helping learners to deal appropriately with challenges and difficulties is of the utmost importance.

There is thus a need to encourage students to adopt a more positive approach to success and failure, to become more adaptive in their attributions. Several authors (e.g., Dörnyei, 2001) have highlighted the importance of encouraging effort attributions, but, as claimed by authors such as Covington (1998), some students equate trying hard with low ability - if one were able, then one would not need to try so hard. Strategy attributions seem to avoid this problem. Covington (1998) argued that "the concept of learning strategies bridges the domains of effort and ability, so that trying hard, but in sophisticated, strategic ways, is tantamount to increasing one's ability to learn" (p. 71). A growing number of publications (e.g., Brophy, 1998; Dörnyei, 2001) have outlined approaches that can be followed to encourage strategy attributions in learners. Perhaps the most important is learner strategy instruction (LST), which (a) makes learners aware of the possibility of improving their learning by employing strategies 
appropriately and effectively; (b) models a range of strategies within the context of normal class language tasks; (c) provides them with guided practice in strategy use; and (d) incorporates evaluation of the effect of strategies used on learning outcomes and action-planning for future strategy use. Various publications (e.g., Cohen, 1998; Macaro, 2001; Oxford, 1990) have outlined practical ways of implementing such instruction.

The first and last of the stages outlined above are of particular importance in encouraging strategy attributions. As Zimmerman and Martinez-Pons (1992) made clear, learners should be invited to explore fully the link between strategy use and learning outcomes, perhaps by planning strategies to try in the light of problems identified, noting which strategies helped and which did not, and why. Hence their degree of metacognitive awareness needs to be enhanced: the ability to stand back and reflect on how and why learning has or has not taken place, to evaluate the strategies used, and to think about what the next steps might be in approaching a task or improving one's learning (Chamot, Barnhardt, El-Dinary, \& Robbins, 1996). This awareness in turn is likely to strengthen their sense of control over their learning (Oxford \& Leaver, 1996).

Studies that have looked at the effect of LST have tended to 
investigate its impact on language proficiency and generally report a significant but modest degree of improvement (e.g., Macaro, 2001, in writing; Thompson \& Rubin, 1996, in listening comprehension). Very few studies have looked at the effect of strategy instruction on selfefficacy and motivation, however. Given the complex relationship between self-efficacy/motivation and proficiency and the uncertainty that persists regarding the direction of causality, both types of study are worthy of further investigation.

The teacher has a central role to play in encouraging adaptive attributions. Dörnyei (2001), discussing the promotion of effort attributions, suggested that teachers should model these attributions themselves, perhaps by thinking aloud while demonstrating a language task and emphasising how persistence will lead to success. This suggestion applies even more strongly to the modelling of strategy attributions, whereby the teacher makes clear that he or she is confident of overcoming any problems by applying appropriate strategies. Similarly, feedback on tasks completed should comment not only on language-related success but also on the effectiveness of strategies employed and listed by the student. Suggestions by the teacher for alternative strategies could also be included in the feedback. 
The findings of this study highlight the need for research to investigate many of the above issues, and in particular, methods for improving learning strategy use and its influence on self-efficacy and hence motivation. Such research is particularly important in contexts where the number of learners continuing specialised language study in postcompulsory education is in decline and the pool from which future teachers of language can be drawn is shrinking. Yet its importance extends beyond this context, however, to all contexts in which language learning leaves students unsure of the route to progress, unable to identify any causes or solutions for their difficulties other than blaming the nature of the work and their own supposed lack of linguistic ability. 
$\underline{\text { Acknowledgments }}$

The research described in this article was funded by a grant from the University of Reading's Research Endowment Trust Fund.

I would like to thank the following: Professor Brian Richards and Professor David Malvern, and four anonymous reviewers, for their helpful comments on earlier drafts of the article; Dr. Ernesto Macaro, for guiding my thinking on questions of causality; and Dr. Daguo Li, for his assistance with data input. 
NOTES

1. In view of the differences between the educational systems of England and the United States, and in the social make-up of the two countries (i.e., the presence in the United States of large numbers of native speakers of Spanish, for which there is no near equivalent in England), a detailed comparison of students' attitudes toward foreign language learning in the two countries has not been attempted.

2. This was the case at the time of the present study. In 2003, however, the Qualifications and Curriculum Authority announced that from September 2004, foreign language study would cease to be compulsory for all students after 14 years of age.

3. Students' motivation for learning a language is a vast theme and a full exploration of all the possible reasons for low motivation is beyond the scope of this article. For a useful overview of theoretical and practical approaches to the question, see Dörnyei (2001).

4. For the GCSE examination, eight grades are awarded, from $\mathrm{G}$ to $\mathrm{A}^{*}$ (the highest grade, followed by Grade A); for the AS- and A examinations, five grades are awarded, from $\mathrm{E}$ to $\mathrm{A}$ (the highest). 
5. Because the questionnaire was completed quite early in the academic year, when Year 12 students had only recently started their post-16 course, few students in that group knew what their teacher's grade prediction might be. Therefore, this year group was excluded from teacher-student grade comparison.

6. In order to avoid obtaining significant results by chance, for multiple comparisons, a Bonferroni adjustment was made (see Bryman \& Cramer, 2001; Siegel \& Castellan, 1988), by dividing the alpha level (0.05) by the number of comparisons made (3), adjusting the alpha level to 0.017 .

7. See Note 6. 


\section{REFERENCES}

Bandura, A. (1993). Perceived self-efficacy in cognitive development and functioning. Educational Psychologist, 28, 117-148.

Bandura, A. (Ed.). (1995). Self-efficacy in changing societies.

Cambridge: Cambridge University Press.

Brophy, J. (1998). Failure syndrome students. ERIC Digest Report

No: EDO-PS-98-2. Retrieved January 29, 2003 from the World Wide

Web: http://www.firstsearch.oclc.org

Bryman, A., \& Cramer, D. (2001). Quantitative data analysis with SPSS Release 10. A guide for social scientists. Hove, England: Routledge.

Chambers, G. (1999). Motivating language learners. Clevedon, England: Multilingual Matters.

Chamot, A. U., Barnhardt, S., El-Dinary, P., \& Robbins, J. (1996).

Methods for teaching learning strategies in the foreign language classroom. In R. L. Oxford (Ed.), Language learning strategies around 
the world: Cross-cultural perspectives (pp. 175-187). (Tech. Rep. No. 13). Honolulu, HI: University of Hawai'i Press.

Chan, L. K. S. (1996). Motivational orientations and metacognitive abilities of intellectually gifted students. Gifted Child Quarterly, 40(4), 184-193.

CILT Direct languages yearbook. (2001). London: CILT

Clifford, M. M. (1986). The comparative effects of strategy and effort attributions. British Journal of Educational Research, 56, 75-83.

Cohen, A. D. (1998). Strategies in learning and using a second language. Harlow, England: Longman.

Cohen, L., \& Manion, L. (1990). Research methods in education. London: Routledge.

Covington, M. V. (1998). The will to learn. A guide for motivating young people. Cambridge: Cambridge University Press.

Dickinson, L. (1995). Autonomy and motivation: A literature review. System, 23(2), 165-174. 
Postsecondary education. (2001). Digest of Education Statistics

(Chapt. 3).. Retrieved January 29, 2003, from:

http://www.nces.ed.gov//pubs2002/digest2001/tables/dt292.asp

Dörnyei, Z. (2001). Motivational strategies in the language classroom. Cambridge: Cambridge University Press.

Dörnyei, Z., \& Csizér, K. 2002). Some dynamics of language attitudes and motivation: Results of a longitudinal nationwide survey. Applied Linguistics, 23(4), 421-462.

Dupuy, B., \& Krashen, S. D. (1998). From lower-division to upperdivision foreign language classes: Obstacles to reaching the promised land. ITL: Review of Applied Linguistics, 119-120, 1-7.

Dweck, C. S. (1987, April). Children's theories of intelligence:

Implications for motivation and learning. Paper presented at the annual meeting of the American Educational Research Association, Washington, DC. 
Dweck, C. S. \& Repucci, N. D. (1973). Learned helplessness and intellectual achievement. Journal of Personality and Social Psychology, 31, 109-116.

Ehrman, M. (1996). An exploration of adult language learner motivation, self-efficacy, and anxiety. In R. L. Oxford (Ed.), Language learning motivation: Pathways to the new century (pp.81-103). (Tech. Rep. No. 11). Honolulu, HI: University of Hawai'i Press.

Fisher, L. (2001). Modern foreign languages recruitment post-16: The pupils' perspective. Language Learning Journal, 23, 33-40.

Ganschow, L., Sparks, R. L., \& Javorsky, J. (1998). Foreign language learning difficulties: An historical perspective. Journal of Learning Disabilities, 31(3), 248-258.

Graham, S. (1994). Classroom motivation from an attributional perspective. In H. F. O'Neil \& M. Drillings (Eds.), Motivation: Theory and research (pp. 31-48). Hillsdale, NJ: Erlbaum.

Graham, S. (1997). Effective language learning. Positive strategies for advanced level language learning. Clevedon, England: Multilingual Matters. 
Graham, S. (2002). Experiences of learning French: A snapshot at years 11, 12 and 13. Language Learning Journal, 25, 15-20.

Horwitz, E. (1988). The beliefs about language learning of beginning university foreign language students. Modern Language Journal, 72, 283-294.

JCGQ (2002). Joint Council for General Qualifications. Retrieved February 13, 2003, from:

http://www.jcgq.org.uk/Exam_Result_data/A_level_Statistics_Summer 2002.pdf

Lambert, R. D. (2001). Updating the foreign language agenda. Modern Language Journal, 85, 347-362.

Macaro, E. (2001). Learning strategies in foreign and second language classrooms. London: Continuum.

Marshall, K. (2000a). What turns them on and what turns them off? Factors influencing pupils' decisions whether or not to take a foreign language to A level and beyond. In G. Chambers (Ed.), Reflections on motivation (pp. 51-60). London: CILT. 
Marshall, K. (2000b, December 12). Babel rebuilt? Guardian Education, 14-15.

Noel, J. G., Forsyth, D. R., \& Kelley, K. N. (1987). Improving the performance of failing students by overcoming their self-serving attributional biases. Basic and Applied Psychology, 8, 151-162.

Oxford, R. L. (1990). Language learning strategies: What every teacher should know. Boston: Heinle.

Oxford, R. L. (Ed.). (1996). Language learning strategies around the world: Cross-cultural perspectives. (Tech. Rep. No. 13). Honolulu, HI: University of Hawai'i Press.

Oxford, R. L., \& Leaver, B. L. (1996). A synthesis of strategy instruction for language learners. In R. L. Oxford (Ed.), Language learning strategies around the world: Cross-cultural perspectives (pp. 227-246). (Tech. Rep. No. 13). Honolulu, HI: University of Hawai'i Press. 
Oxford, R. L., \& Shearin, J. (1994). Language learning motivation: Expanding the theoretical framework. Modern Language Journal, 78, $12-28$

QCA (Qualifications \& Curriculum Authority ). (2001). Subject criteria: Modern foreign languages. Retrieved January 29, 2003 from: http://www.qca.org.uk/nq/subjects/mfl.asp

Schulz, R. A. (1998). Foreign language education in the United States: Trends and challenges. Retrieved January 29, 2003 from: http://eric.ed.gov/resources/ericreview/vol6no1/index.html

Seligman, M. P. (1975). Learned helplessness: On depression, development and death. San Francisco: Freeman.

Siegel, S., \& Castellan, N. J. (1988). Nonparametric statistics for the behavioral sciences, $2^{\text {nd }}$ ed. New York: McGraw-Hill.

Simon, P. (1980). The tongue-tied American. New York: Continuum.

Stables, A., \& Stables, S. (1996). Modern Languages at A-level: The danger of curricular discontinuity. Language Learning Journal 2 14, 5052. 
Stern, H. H. (1983). Fundamental concepts of language teaching.

Oxford: Oxford University Press.

Thompson, I., \& Rubin, J. (1996). Can strategy instruction improve listening comprehension? Foreign Language Annals, 29(3), 331-342.

Tremblay, P. F., \& Gardner, R. C. (1995). Expanding the motivation construct in language learning. Modern Language Journal, 79, 505520.

Tse, L. (2000). Student perceptions of foreign language study: A qualitative analysis of foreign language biographies. Modern Language Journal, 84, 69-84.

Weiner, B. (1984). Principles for a theory of student motivation and their application within an attributional framework. In R. E. Ames \& C. Ames (Eds.), Research on motivation in education, Vol. 1 (pp. 1537). Orlando: Academic Press. 
Whitley, B. E., \& Frieze, I. H. (1985). Children's causal attributions for success and failure in achievement settings: A meta-analysis. Journal of Educational Psychology, 77(5), 608-616.

Williams, M., \& Burden, R. (1999). Students' developing conceptions of themselves as language learners. Modern Language Journal, 83, 193-201.

Williams, M., Burden, R., \& Lanvers, U. (2002). 'French is the language of love and stuff': Student perceptions of issues related to motivation in learning a foreign language. British Educational Research Journal, 28(4), 503-549.

Yang, N-D. (1999). The relationship between EFL learners' beliefs and learning strategy use. System, 27(4), 515-535

Zimmerman, B. J. (1995). Self-efficacy and educational development. In Bandura, A. (Ed.), Self-efficacy in changing societies, (pp. 202231). Cambridge: Cambridge University Press.

Zimmerman, B. J., \& Martinez-Pons, M. (1992). Perceptions of efficacy and strategy use in the self-regulation of learning. In D. H. 
Schunk \& J. L. Meece (Eds.), Student perceptions in the classroom (pp. 185-207). Hillsdale, N.J.: Lawrence Erlbaum Associates. 


\section{APPENDIX A - QUESTIONNAIRE ITEMS}

A. Items common to Year 11, 12, and 13 questionnaires:

1. How well are you doing in French? Circle the one number from 1 to 6 which best matches how you feel. The higher the number you ring, the better you think you are doing.

I am doing

very well

in French
I am doing very badly

in French

$\begin{array}{llllll}1 & 2 & 3 & 4 & 5 & 6\end{array}$

2. Please complete the following statements:

a) 'When I do well in French, it's usually because

b) 'When I don't do so well in French, it's usually because

3. Think about areas in French in which you have done well (e.g., listening, speaking, reading, writing, grammar, etc.). Name the one area where you have had the most success: 
4. Why have you been successful in this area, do you think? Circle the one number from 1 to 6 which best matches how you feel about each reason below.

I've been successful in this area because.......

$\begin{array}{ll}\text { Agree } & \text { Disagree } \\ \text { Strongly } & \text { strongly }\end{array}$

$\begin{array}{lllllll}\text { I'm just good at that kind of thing } & 1 & 2 & 3 & 4 & 5 & 6 \\ \text { It's just luck } & 1 & 2 & 3 & 4 & 5 & 6 \\ \text { I try hard } & 1 & 2 & 3 & 4 & 5 & 6 \\ \text { I use good techniques or strategies } & 1 & 2 & 3 & 4 & 5 & 6 \\ \text { We're given easy work } & 1 & 2 & 3 & 4 & 5 & 6\end{array}$

Are there other reasons? Write them here

5. Now think about areas in French in which you have not done so well (e.g. listening, speaking, reading, writing, grammar, etc.). Name the one area where you have had the least success: 
6. Why have you been less successful in this area, do you think?

Circle the one number from 1 to 6 which best matches how you feel about each reason below.

I've been less successful in this area because....

$\begin{array}{cc}\text { Agree } & \text { Disagree } \\ \text { strongly } & \text { strongly }\end{array}$

$\begin{array}{lllllll}\text { I don't try very hard } & 1 & 2 & 3 & 4 & 5 & 6 \\ \text { I use poor techniques or strategies } & 1 & 2 & 3 & 4 & 5 & 6 \\ \text { I'm just no good at that kind of thing } & 1 & 2 & 3 & 4 & 5 & 6 \\ \text { We're given difficult work } & 1 & 2 & 3 & 4 & 5 & 6 \\ \text { It's just bad luck } & 1 & 2 & 3 & 4 & 5 & 6\end{array}$

Are there other reasons? Write them here

B. Items from the Year 11 questionnaire

7a. What grade does your teacher say you will get for GCSE French?

7b. What grade do you think you will get for GCSE French?

8a. How hard will you have to work to get the grade you hope to achieve? Circle the one number from 1 to 6 which best matches how you feel.

Not hard
at all
$\begin{array}{llllll} & & & \text { Very hard } \\ 1 & 2 & 3 & 4 & 5 & 6\end{array}$


8b. Please explain your answer to Question 8a.

9a. Do you hope to study French at AS- or A-level ? Yes / No / Not sure (ring one).

9b. Please explain your reasons:

C. Items from the Year 12 questionnaire

10. What grade did you get for GCSE French?

11a. How hard did you have to work to get this grade? Circle the one number from 1 to 6 which best matches how you feel.

Not hard

at all

12
34
Very hard

$5 \quad 6$

11b. Please explain your answer to Question 11a.

12a. What grade does your teacher say you will get for AS French?

12b. What grade do you think you will get for AS French?

13a. How hard will you have to work to get the grade you hope to achieve? Circle the one number from 1 to 6 which best matches how you feel.

Not hard

Very hard

at all

$\begin{array}{llllll}1 & 2 & 3 & 4 & 5 & 6\end{array}$


13b. Please explain your answer to Question 13a.

14. Why did you choose to study French at AS-level?

D. Items from the Year 13 questionnaire

15. What grade did you get for GCSE French?

16. What grade did you get for AS French?

17a. How hard did you have to work to get this grade for AS French?

Circle the one number from 1 to 6 which best matches how you feel.

Not hard

at all

12

2

4

5

6

17b. Please explain your answer to Question 17a.

18a. What grade does your teacher say you will get for A-level

French?

18b. What grade do you think you will get for A-level French?

19a. How hard will you have to work to get the grade you hope to achieve? Circle the one number from 1 to 6 which best matches how you feel.

Not hard

Very hard

at all

$\begin{array}{llllll}1 & 2 & 3 & 4 & 5 & 6\end{array}$

19b. Please explain your answer to Question 19a.

20. Why did you choose to study French at A-level? 


\section{TABLE 1}

Number of Candidates Sitting A-Level French Examinations in England, Wales, and Northern Ireland, 1990-2002

\begin{tabular}{ll}
\hline \hline Date & French \\
1990 & 27,245 \\
1991 & 30,794 \\
1992 & 31,261 \\
1993 & 29,862 \\
1994 & 28,942 \\
1995 & 27,563 \\
1996 & 27,728 \\
1997 & 26,488 \\
1998 & 23,979 \\
1999 & 21,072 \\
2000 & 18,228 \\
2001 & 17,939 \\
2002 & 15,615 \\
\hline
\end{tabular}

Note. (Data from CILT Direct Languages Yearbook, 2001; JCGQ, 2002). England, Wales, and Northern Ireland have a common examination framework and so national bodies record statistics for these three countries. 


\section{TABLE 2}

Numbers of Respondents to Questionnaire by Year Group and Gender

\begin{tabular}{lccc}
\hline \hline & Year 11 & Year 12 & Year 13 \\
Male & 130 & 57 & 33 \\
Female & 156 & 145 & 73 \\
Totals & 286 & 202 & 106 \\
\hline
\end{tabular}


TABLE 3

GCSE Grades Predicted by Teacher or Received

\begin{tabular}{lcccccccc}
\hline \hline & \multicolumn{7}{c}{ GCSE Grades } \\
\hline Year Group & A* & A & B & C & D & E & F & G \\
Year 11 & 44 & 75 & 81 & 56 & 17 & 3 & 1 & 0 \\
Predicted & $(16 \%)$ & $(27 \%)$ & $(29 \%)$ & $(20 \%)$ & $(6 \%)$ & $(1 \%)$ & $(0.5 \%)$ & $(0 \%)$ \\
Year 12 & 123 & 49 & 18 & 9 & $1(0.5 \%)$ & 0 & 0 & 0 \\
Received & $(62 \%)$ & $(25 \%)$ & $(9 \%)$ & $(5 \%)$ & & $(0 \%)$ & $(0 \%)$ & $(0 \%)$ \\
Year 13 & 67 & 30 & 7 & 2 & 0 & 0 & 0 & 0 \\
Received & $(63 \%)$ & $(29 \%)$ & $(7 \%)$ & $(2 \%)$ & $(0 \%)$ & $(0 \%)$ & $(0 \%)$ & $(0 \%)$ \\
\hline
\end{tabular}

Note. The GCSE examination awards grades on a scale of $\mathrm{A}^{*}$ to $\mathrm{G}$, with $\mathrm{A}^{*}$ the highest. Rounding means that some percentages may not total 100 . 
TABLE 4

Comparison of Grades Predicted by Teachers and by Pupils

GCSE Grades

\begin{tabular}{|c|c|c|c|c|c|c|c|c|}
\hline $\begin{array}{l}\text { Year Group } \\
\text { (Predictor) }\end{array}$ & $\mathrm{A}^{*}$ & $\mathrm{~A}$ & $\mathrm{~B}$ & $\mathrm{C}$ & $\mathrm{D}$ & $\mathrm{E}$ & $\mathrm{F}$ & G \\
\hline $\begin{array}{l}11 \\
\text { (Pupil ) }\end{array}$ & $\begin{array}{c}20 \\
(7 \%)\end{array}$ & $\begin{array}{c}68 \\
(24 \%)\end{array}$ & $\begin{array}{c}106 \\
(37 \%)\end{array}$ & $\begin{array}{c}63 \\
(22 \%)\end{array}$ & $\begin{array}{c}21 \\
(7 \%)\end{array}$ & $\begin{array}{c}3 \\
(1 \%)\end{array}$ & $\begin{array}{c}5 \\
(2 \%)\end{array}$ & $\begin{array}{c}0 \\
(0 \%)\end{array}$ \\
\hline $\begin{array}{l}11 \\
\text { (Teacher) }\end{array}$ & $\begin{array}{c}44 \\
(16 \%)\end{array}$ & $\begin{array}{c}75 \\
(27 \%)\end{array}$ & $\begin{array}{c}81 \\
(29 \%)\end{array}$ & $\begin{array}{c}56 \\
(20 \%)\end{array}$ & $\begin{array}{c}17 \\
(6 \%)\end{array}$ & $\begin{array}{c}3 \\
(1 \%)\end{array}$ & $\begin{array}{c}1 \\
(0.5 \%)\end{array}$ & $\begin{array}{c}0 \\
(0 \%)\end{array}$ \\
\hline \multicolumn{9}{|c|}{ AS and A Level Grades } \\
\hline & \multicolumn{2}{|c|}{ A } & B & $\mathrm{C}$ & \multicolumn{2}{|l|}{$\mathrm{D}$} & \multicolumn{2}{|l|}{$\mathrm{E}$} \\
\hline $\begin{array}{l}12 \\
\text { (Pupil) }\end{array}$ & \multicolumn{2}{|c|}{$\begin{array}{c}62 \\
(33 \%)\end{array}$} & $\begin{array}{c}79 \\
(42 \%)\end{array}$ & $\begin{array}{c}41 \\
(22 \%)\end{array}$ & \multicolumn{2}{|l|}{$\begin{array}{c}7 \\
(4 \%)\end{array}$} & \multicolumn{2}{|l|}{$\begin{array}{c}0 \\
(0 \%)\end{array}$} \\
\hline \multicolumn{9}{|c|}{12 (No Prediction by Teacher ${ }^{a}$ ) } \\
\hline $\begin{array}{l}13 \\
\text { (Pupil) }\end{array}$ & \multicolumn{2}{|c|}{$\begin{array}{c}53 \\
(51 \%)\end{array}$} & $\begin{array}{c}35 \\
(33 \%)\end{array}$ & $\begin{array}{c}13 \\
(12 \%)\end{array}$ & $\begin{array}{c}4 \\
(4 \%)\end{array}$ & & \multicolumn{2}{|l|}{$\begin{array}{c}0 \\
(0 \%)\end{array}$} \\
\hline $\begin{array}{l}13 \\
\text { (Teacher) }\end{array}$ & \multicolumn{2}{|c|}{$\begin{array}{c}57 \\
(56 \%)\end{array}$} & $\begin{array}{c}25 \\
(25 \%)\end{array}$ & $\begin{array}{c}14 \\
(14 \%)\end{array}$ & $\begin{array}{c}6 \\
(6 \%)\end{array}$ & & \multicolumn{2}{|l|}{$\begin{array}{c}0 \\
(0 \%)\end{array}$} \\
\hline
\end{tabular}

Note. The GCSE examination awards grades on a scale of $A^{*}$ to $\mathrm{G}$, with $\mathrm{A} *$ the highest. Rounding means that some percentages may not total 100 . The AS and A level grades are awarded on a scale of A to E. ${ }^{a}$ Very few Year 12 pupils gave a grade predicted by their teacher (possibly because at an early point in their post-16 course, no such prediction had been made); therefore only pupil predictions are given for this year group 


\section{TABLE 5}

Comparison of GCSE Grades Predicted for Year 11 by Teachers and by Pupils, by Gender GCSE Grades

\begin{tabular}{lcccccccc}
\hline $\begin{array}{l}\text { Gender } \\
\text { (Predictor) }\end{array}$ & $\mathrm{A}^{*}$ & $\mathrm{~A}$ & $\mathrm{~B}$ & $\mathrm{C}$ & $\mathrm{D}$ & $\mathrm{E}$ & $\mathrm{F}$ & $\mathrm{G}$ \\
$\begin{array}{l}\text { Male } \\
\text { (Pupil) }\end{array}$ & 7 & 23 & 51 & 32 & 11 & 2 & 4 & 0 \\
Male & $(5 \%)$ & $(18 \%)$ & $(39 \%)$ & $(25 \%)$ & $(9 \%)$ & $(2 \%)$ & $(3 \%)$ & $(0 \%)$ \\
(Teacher) & 8 & 29 & 40 & 33 & 12 & 2 & 0 & 0 \\
& $(7 \%)$ & $(23 \%)$ & $(32)$ & $(27 \%)$ & $(10 \%)$ & $(2 \%)$ & $(0 \%)$ & $(0 \%)$ \\
\hline Female & 13 & 45 & 55 & 31 & 9 & 1 & 1 & 0 \\
(Pupil) & $(8 \%)$ & $(29 \%)$ & $(36 \%)$ & $(20 \%)$ & $(6 \%)$ & $(1 \%)$ & $(1 \%)$ & $(0 \%)$ \\
Female & 36 & 46 & 41 & 22 & 5 & 1 & 1 & 0 \\
(Teacher) & $(24 \%)$ & $(30 \%)$ & $(27 \%)$ & $(15 \%)$ & $(3 \%)$ & $(1 \%)$ & $(1 \%)$ & $(0 \%)$ \\
& & & & & & & & \\
\end{tabular}

Note. The GCSE examination awards grades on a scale of $\mathrm{A}^{*}$ to $\mathrm{G}$, with $\mathrm{A}$ * the highest. Rounding means that some percentages may not total 100. The AS and A level grades are awarded on a scale of A to E. 
TABLE 6

Attributions for Overall Achievement in French

\begin{tabular}{|c|c|c|}
\hline \multicolumn{3}{|c|}{ Success Attributions } \\
\hline \multicolumn{3}{|c|}{ When I do well in French, it's usually because (of) } \\
\hline & $N$ & $\%$ \\
\hline \multicolumn{3}{|l|}{ Year 11} \\
\hline Ability ${ }^{\mathrm{a}}$ & 79 & 28 \\
\hline Effort & 45 & 16 \\
\hline Concentration & 45 & 16 \\
\hline Strategy, Way of Working ${ }^{\mathrm{b}}$ & 39 & 14 \\
\hline Interest, Enjoyment & 28 & 10 \\
\hline \multicolumn{3}{|l|}{ Year 12} \\
\hline Effort & 45 & 23 \\
\hline Ability $^{\mathrm{a}}$ & 44 & 22 \\
\hline Strategy, Way of Working ${ }^{b}$ & 33 & 17 \\
\hline Interest, Enjoyment & 24 & 12 \\
\hline Concentration & 15 & 8 \\
\hline \multicolumn{3}{|l|}{ Year 13} \\
\hline Effort & 40 & 38 \\
\hline Strategy, Way of Working ${ }^{\mathrm{b}}$ & 22 & 21 \\
\hline Interest, Enjoyment & 19 & 18 \\
\hline Ability $^{\mathrm{a}}$ & 8 & 8 \\
\hline Concentration & 6 & 6 \\
\hline
\end{tabular}

Failure Attributions

\begin{tabular}{|c|c|c|}
\hline \multicolumn{3}{|l|}{ Year 11} \\
\hline Low Ability ${ }^{\mathrm{a}}$ & 104 & 36 \\
\hline Poor Concentration & 51 & 18 \\
\hline Lack of Effort & 25 & 9 \\
\hline Poor Strategies, Way of Working ${ }^{\mathrm{b}}$ & 22 & 8 \\
\hline Lack of Interest, Enjoyment & 21 & 7 \\
\hline \multicolumn{3}{|l|}{ Year 12} \\
\hline Low Ability ${ }^{\mathrm{a}}$ & 56 & 28 \\
\hline Task Difficulty & 29 & 15 \\
\hline Poor Strategies, Way of Working & 25 & 13 \\
\hline Lack of Effort & 24 & 12 \\
\hline Poor Concentration & 21 & 11 \\
\hline \multicolumn{3}{|l|}{ Year 13} \\
\hline Lack of Effort & 26 & 25 \\
\hline Low Ability ${ }^{\mathrm{a}}$ & 16 & 15 \\
\hline Poor Strategies, Way of Working ${ }^{b}$ & 16 & 15 \\
\hline Mood/Other Affect & 11 & 11 \\
\hline Poor Concentration & 10 & 10 \\
\hline
\end{tabular}

Note. Percentages do not total 100 because reasons given by very small numbers of respondents have not been reported.

${ }^{a}$ Ability encompasses possession of ability, knowledge, understanding, or skill.

${ }^{\mathrm{b}}$ Strategy/strategies include revising, reviewing work. 
TABLE 7

Attributions for Success in Specific Areas, by Year Group (Percentages)

\begin{tabular}{|c|c|c|c|c|c|c|}
\hline \multirow[t]{2}{*}{ Attribution } & \multicolumn{6}{|c|}{ Response Scale } \\
\hline & 1 & 2 & 3 & 4 & 5 & 6 \\
\hline \multicolumn{7}{|l|}{ Year 11} \\
\hline Good at that kind of thing & 4.9 & 7.4 & 24.6 & 32.6 & 21.8 & 8.8 \\
\hline Luck & 29.1 & 28.8 & 18.6 & 11.6 & 8.4 & 3.5 \\
\hline Try hard & 2.5 & 4.9 & 9.2 & 23.6 & 39.4 & 20.4 \\
\hline Good techniques or strategies & 4.3 & 13.1 & 20.9 & 33.0 & 23.8 & 5.0 \\
\hline Easy work & 34.2 & 33.5 & 18.3 & 7.4 & 4.9 & 1.8 \\
\hline \multicolumn{7}{|l|}{ Year 12} \\
\hline Good at that kind of thing & 0.5 & 4.0 & 12.1 & 34.2 & 34.2 & 15.1 \\
\hline Luck & 37.1 & 33.5 & 16.8 & 9.1 & 3.6 & 0 \\
\hline Try hard & 2.0 & 2.0 & 7.1 & 25.4 & 39.1 & 24.4 \\
\hline Good techniques or strategies & 2.0 & 8.1 & 18.7 & 35.4 & 28.3 & 7.6 \\
\hline Easy work & 32.5 & 42.1 & 12.7 & 8.1 & 4.1 & 0.5 \\
\hline \multicolumn{7}{|l|}{ Year 13} \\
\hline Good at that kind of thing & 1.9 & 5.7 & 12.3 & 25.5 & 34.9 & 19.8 \\
\hline Luck & 44.8 & 37.1 & 10.5 & 5.7 & 1.0 & 1.0 \\
\hline Try hard & 0 & 7.6 & 7.6 & 30.5 & 37.1 & 17.1 \\
\hline Good techniques or strategies & 2.9 & 4.8 & 18.1 & 34.3 & 31.4 & 8.6 \\
\hline Easy work & 36.8 & 42.5 & 15.1 & 3.8 & 0.9 & 0.9 \\
\hline
\end{tabular}

Note. 1 = disagree strongly, $6=$ agree strongly. 
TABLE 8

Attributions for Lack of Success in Specific Areas, by Year Group (Percentages)

\begin{tabular}{|c|c|c|c|c|c|c|}
\hline \multirow[t]{2}{*}{ Attribution } & \multicolumn{6}{|c|}{ Response Scale } \\
\hline & 1 & 2 & 3 & 4 & 5 & 6 \\
\hline \multicolumn{7}{|l|}{ Year 11} \\
\hline No good at that kind of thing & 4.9 & 13.1 & 18.7 & 26.5 & 24.7 & 12.0 \\
\hline Bad luck & 37.4 & 26.0 & 17.8 & 11.0 & 5.0 & 2.8 \\
\hline Don't try very hard & 31.0 & 38.4 & 14.4 & 8.5 & 5.3 & 2.5 \\
\hline Poor techniques or strategies & 11.0 & 23.1 & 31.7 & 19.2 & 11.7 & 3.2 \\
\hline Difficult work & 5.0 & 16.3 & 27.0 & 26.2 & 16.7 & 8.9 \\
\hline \multicolumn{7}{|l|}{ Year 12} \\
\hline No good at that kind of thing & 7.7 & 22.4 & 19.9 & 24.0 & 17.9 & 8.2 \\
\hline Bad luck & 40.5 & 30.8 & 13.3 & 12.3 & 2.1 & 1.0 \\
\hline Don’t try very hard & 33.8 & 33.8 & 14.6 & 9.6 & 8.1 & 0 \\
\hline Poor techniques or strategies & 12.6 & 26.3 & 28.8 & 20.7 & 10.1 & 1.5 \\
\hline Difficult work & 5.6 & 15.2 & 26.9 & 22.8 & 19.3 & 10.2 \\
\hline \multicolumn{7}{|l|}{ Year 13} \\
\hline No good at that kind of thing & 9.5 & 23.8 & 21.0 & 21.9 & 21.0 & 2.9 \\
\hline Bad luck & 60.0 & 21.9 & 7.6 & 6.7 & 1.0 & 2.9 \\
\hline Don't try very hard & 29.2 & 31.1 & 19.8 & 11.3 & 6.6 & 1.9 \\
\hline Poor techniques or strategies & 10.6 & 27.9 & 21.2 & 27.9 & 11.5 & 1.0 \\
\hline Difficult work & 12.3 & 24.5 & 19.8 & 20.8 & 18.9 & 3.8 \\
\hline
\end{tabular}

Note. 1 = disagree strongly; 6 = agree strongly. 
TABLE 9

Post Hoc Multiple Comparisons between Key Attributions (Within-Subjects, Wilcoxon Matched-Pairs Signed-Ranks Test)

Year $11(n=286)$

Effort vs. Strategy Use

Ability vs. Strategy Use

Effort vs. Ability

Year $12(n=202)$

Effort vs. Strategy Use

Ability vs. Strategy Use

Effort vs. Ability

Year $13(n=106)$

Effort vs. Strategy Use

Ability vs. Strategy Use

Effort vs. Ability

Year $11(n=286)$

Low Ability vs. Poor Strategy Use

Task Difficulty vs. Poor Strategy Use

Low Ability vs. Task Difficulty

Year $12(n=202)$

Low Ability vs. Poor Strategy Use

Task Difficulty vs. Poor Strategy Use

Task Difficulty vs. Low Ability

Year $13(n=106)$

Low Ability vs. Poor Strategy Use

Task Difficulty vs. Poor Strategy Use

Success Attributions

Task Difficulty vs. Low Ability

Failure Attributions

Sig.

.000

.334

.000

$-6.458$

.000

$-6.53$

.000

$-3.637$

.009

$-3.053$

.002

$-2.566$

.01

$-.124$

.901

Note. In each pair, the first attribution given is the one with the higher score, indicating a higher level of agreement with the attributional statement. 
TABLE 10

Percentages of Year 11 Attributions for Success in Specific Areas, by Desire to Continue Studying French Post-16

\begin{tabular}{|c|c|c|c|c|c|c|}
\hline \multirow[t]{2}{*}{ Attribution } & \multicolumn{6}{|c|}{ Response Scale } \\
\hline & 1 & 2 & 3 & 4 & 5 & 6 \\
\hline \multicolumn{7}{|l|}{ Continuers $(N=55)$} \\
\hline Good at that kind of thing & 1.8 & 9.1 & 14.5 & 34.5 & 21.8 & 18.2 \\
\hline Luck & 47.3 & 32.7 & 12.7 & 5.5 & 1.8 & 0 \\
\hline Try hard & 0 & 3.6 & 3.6 & 14.5 & 49.1 & 29.1 \\
\hline Good techniques or strategies & 0 & 9.1 & 21.8 & 30.9 & 30.9 & 7.3 \\
\hline Easy work & 38.2 & 38.2 & 14.5 & 7.3 & 1.8 & 0 \\
\hline \multicolumn{7}{|l|}{ Noncontinuers $(N=150)$} \\
\hline Good at that kind of thing & 8.1 & 9.5 & 21.6 & 35.1 & 19.6 & 6.1 \\
\hline Luck & 20.9 & 25.0 & 20.3 & 14.9 & 12.2 & 6.8 \\
\hline Try hard & 4.8 & 8.2 & 12.9 & 25.2 & 31.3 & 17.7 \\
\hline Good techniques or strategies & 7.5 & 16.3 & 21.1 & 31.3 & 18.4 & 5.4 \\
\hline Easy work & 32.7 & 29.9 & 20.4 & 6.8 & 6.8 & 3.4 \\
\hline \multicolumn{7}{|l|}{ Not Sure $(N=81)$} \\
\hline Good at that kind of thing & 1.2 & 2.5 & 37.0 & 25.9 & 25.9 & 7.4 \\
\hline Luck & 32.1 & 33.3 & 19.8 & 9.9 & 4.9 & 0 \\
\hline Try hard & 0 & 0 & 6.2 & 27.2 & 46.9 & 19.8 \\
\hline Good techniques or strategies & 1.3 & 8.9 & 20.3 & 38.0 & 29.1 & 2.5 \\
\hline Easy work & 33.3 & 37.0 & 17.3 & 8.6 & 3.7 & 0 \\
\hline
\end{tabular}

Note. 1 = disagree strongly; $6=$ agree strongly. 
TABLE 11

Percentages of Year 11 Attributions for Lack of Success in Specific Areas, by Desire to Continue Studying French Post-16

\section{Attribution}

Continuers $(N=55)$

No good at that kind of thing

Bad luck

Don't try very hard

Poor techniques or strategies

Difficult work

Noncontinuers $(N=150)$

No good at that kind of thing

Bad luck

Don't try very hard

Poor techniques or strategies

Difficult work

Not sure $(N=81)$

No good at that kind of thing

Bad luck

Don't try very hard

Poor techniques or strategies

Difficult work
1

$\begin{array}{ll}7.4 & 27.8\end{array}$

40.7

48.1

13.0

13.0

4.1

39.0

29.1

12.9

2.0

5.0

32.5

22.2

6.3

5.0
31.5

37.0

37.0

29.6

8.1

19.9

31.1

19.7

15.6

12.5

32.5

53.1

20.3

7.5

Note. 1 = disagree strongly; 6 = agree strongly.

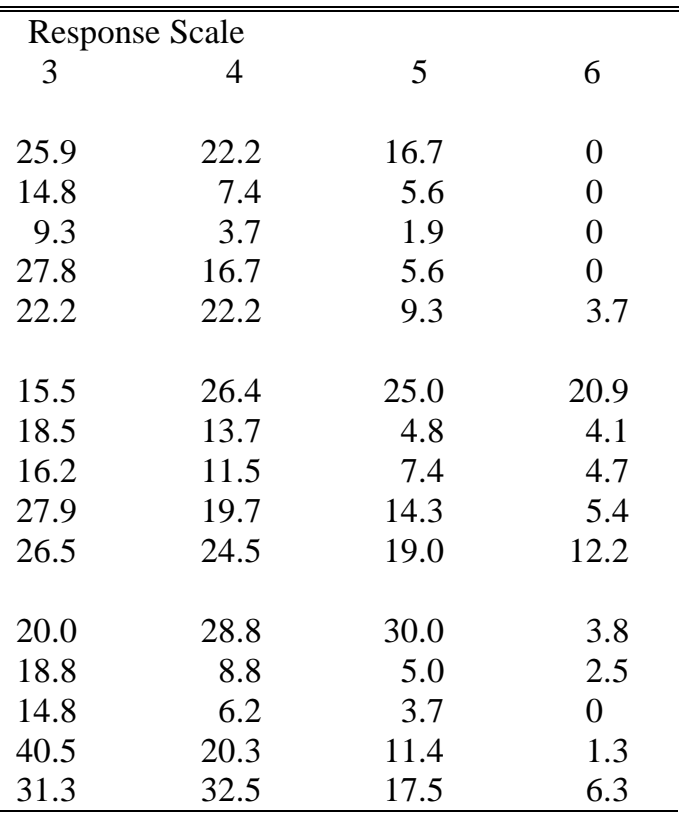

Note. 1 = disagree strongly; 6 agree strongly. 
TABLE 12

Post Hoc Multiple Comparisons According to Desire to Study French PostGCSE (Between-Groups, Mann-Whitney U Test)

\begin{tabular}{l|c|l}
\hline \hline & Continuers versus Noncontinuers & Sig. \\
Success & $z$ & $.013^{\mathrm{a}}$ \\
Ability & -2.474 & $.000^{\mathrm{b}}$ \\
Luck & -4.798 & $.000^{\mathrm{a}}$ \\
Effort & -3.594 & $.013^{\mathrm{a}}$ \\
Strategy Use & -2.493 & \\
Failure & & $.000^{\mathrm{b}}$ \\
Low Ability & -4.937 & $.000^{\mathrm{b}}$ \\
Low Effort & -3.495 & $.013^{\mathrm{b}}$ \\
Poor Strategy Use & -2.488 & $.000^{\mathrm{b}}$ \\
Task Difficulty & -3.729 & \\
Success & Continuers versus Not Sure & $.159^{\mathrm{a}}$ \\
Ability & -1.409 & $.034^{\mathrm{c}}$ \\
Luck & -2.117 & $.133^{\mathrm{a}}$ \\
Effort & -1.502 & $.538^{\mathrm{a}}$ \\
Strategy Use & -.615 & $.004^{\mathrm{c}}$ \\
Failure & & $.004^{\mathrm{c}}$ \\
Low Ability & -2.914 & $.012^{\mathrm{c}}$ \\
Low Effort & -2.891 & $.001^{\mathrm{c}}$ \\
Poor Strategy Use & -2.526 & \\
Task Difficulty & -3.228 & $.236^{\mathrm{c}}$ \\
Success & & $.001^{\mathrm{b}}$ \\
Ability & -1.185 & $.005^{\mathrm{c}}$ \\
Luck & -3.290 & $.026^{\mathrm{c}}$ \\
Effort & -2.835 & $.012^{\mathrm{b}}$ \\
Strategy Use & -2.224 & $.237^{\mathrm{b}}$ \\
Failure & -2.508 & $.869^{\mathrm{b}}$ \\
Low Ability & -1.183 & \\
Low Effort & -.166 & \\
Poor Strategy Use & Noncontinuers versus Not Sure & \\
Task Difficulty & & \\
\hline Indcat & \\
\hline
\end{tabular}

${ }^{\mathrm{a}}$ Indicates a higher level of agreement by yes respondents.

${ }^{\mathrm{b}}$ Indicates a higher level of agreement by no respondents.

${ }^{\mathrm{c}}$ Indicates a higher level of agreement by not sure respondents. 
TABLE 13

Spearman's Rho Correlation Coefficients for Specific Attributions, Self-Predicted GCSE Grade and Achievement Self-Rating, Year 11, $N=286$

\begin{tabular}{lcc}
\hline \hline & Self-Predicted GCSE Grade & Achievement Self-Rating \\
Success Attributions & $.25^{* *}$ & $.24^{* *}$ \\
Ability & $.40^{* *}$ & $.42^{* *}$ \\
Effort & $.29^{* *}$ & $.28^{* *}$ \\
Strategies & $-.34^{* *}$ & $-.38^{*}$ \\
Luck & & \\
Failure Attributions & $-.25^{* *}$ & $-.22^{* *}$ \\
Ability & $-.33^{* *}$ & $-.37^{* *}$ \\
Effort & $-.24^{* *}$ & $-.26^{* *}$ \\
Strategies & $-.14^{*}$ & $-.13^{* *}$ \\
Luck & $-.18^{* *}$ & $-.24^{* *}$ \\
Task Difficulty & & \\
\hline
\end{tabular}
$* p<0.05 . * * p<0.01$. 
TABLE 14

Spearman's Rho Correlation Coefficients for Specific Attributions, Actual GCSE Grade, Self-Predicted AS Grade, and Achievement Self-Rating, Year 12, $N=202$

\begin{tabular}{lccc}
\hline \hline & $\begin{array}{c}\text { GCSE } \\
\text { Grade }\end{array}$ & $\begin{array}{c}\text { Self-Predicted } \\
\text { AS Grade }\end{array}$ & $\begin{array}{c}\text { Achievement } \\
\text { Self-Rating }\end{array}$ \\
Success Attributions & & & $.33^{* *}$ \\
Ability & $.22^{* *}$ & $-.15^{*}$ & $.25^{* *}$ \\
Luck & & $.16^{*}$ & $-.23^{* *}$ \\
Task Ease & & $-.19^{* *}$ & \\
Failure Attributions & $-.24 * *$ & $-.22^{* *}$ \\
Ability & & $-.30^{* *}$ \\
Strategies & & $-.24^{* *}$ \\
Task Difficulty & & & \\
\hline
\end{tabular}

Note. Attributions have been omitted where no significant correlation was found with either variable. ${ }^{*} p<0.05 . * * p<0.01$. 
TABLE 15

Spearman's Rho Correlation Coefficients for Specific Attributions, Actual AS Grade, Self-Predicted A Level Grade, and Achievement Self-Rating, Year 13, $N=106$

\begin{tabular}{|c|c|c|c|}
\hline & $\begin{array}{c}\text { AS } \\
\text { Grade }\end{array}$ & $\begin{array}{l}\text { Self-Predicted } \\
\text { A Level Grade }\end{array}$ & $\begin{array}{l}\text { Achievement } \\
\text { Self-Rating }\end{array}$ \\
\hline \multicolumn{4}{|c|}{ Success Attributions } \\
\hline Ability & $.33^{* *}$ & $.44 * *$ & $.57 * *$ \\
\hline Strategies & $.27 * *$ & $.42 * *$ & $.44 * *$ \\
\hline Luck & & $-.20 *$ & \\
\hline \multicolumn{4}{|c|}{ Failure Attributions } \\
\hline Ability & $-.29 * *$ & $-.42 * *$ & $-.47 * *$ \\
\hline Strategies & & $-.24 *$ & $-.26 * *$ \\
\hline Task Difficulty & $-.34 * *$ & $-.31 * *$ & $-.29 * *$ \\
\hline
\end{tabular}

Note. Attributions have been omitted where no significant correlation was found with either variable. $* p<0.05 . * * p<0.01$. 